\title{
The effectiveness of technologies for the cultivation of winter wheat with different levels of biologization in the conditions of the Kursk region
}

\author{
Oksana Nikitina ${ }^{1 *}$, Vladimir Lazarev ${ }^{2}$ and Anatoly Stifeev ${ }^{1}$ \\ ${ }^{1}$ Ivanov Kursk State Agricultural Academy, Kursk, Russia \\ ${ }^{2}$ Kursk Federal Agrarian Scientific Center, Kursk, Russia
}

\begin{abstract}
The results of studies on the efficiency of winter wheat cultivation technologies, including fertilization systems with different levels of biologization, are presented. It was found that during the cultivation of winter wheat using intensive technology with a mineral fertilization system, the reserves of productive moisture in the arable layer of the soil were almost equal to the reserves of moisture when cultivated using intensive technology (without fertilization). In variants with the cultivation of winter wheat according to the technology with a $50 \%$ level of biologization, the reserves of productive moisture in the arable layer of the soil increased by $0.9 \mathrm{~mm}$, and by a $100 \%$ level - by $1.6 \mathrm{~mm}$. Higher reserves of nitrate-nitrogen in the $0-40 \mathrm{~cm}$ soil layer before sowing winter wheat were noted in variants where it was cultivated using biotechnology with a $100 \%$ supply of nutrients from organic fertilizers. A decrease in the level of biologization of the technology to $50 \%$ led to a decrease in the reserves of nitrate-nitrogen by $2.5 \mathrm{~kg} / \mathrm{ha}$. The highest weediness of winter wheat crops was noted when it was cultivated using technologies with 50 and $100 \%$ biologization levels - 70.6-92.0 pcs/m2. Compared to the mineral fertilization system, when using organic fertilizers, there is an increase in weediness of winter wheat crops by $5.8-18.1 \%$. The highest yield of winter wheat was obtained by cultivating it using intensive technology $-5.98 \mathrm{t} / \mathrm{ha}$. Technologies with 50 and $100 \%$ biologization levels ensured the production of 5.87 and $5.41 \mathrm{t} / \mathrm{ha}$, respectively.
\end{abstract}

\section{Introduction}

The intensive path of development of agricultural production adopted and used at present has contributed to a significant increase in the productivity of agriculture - the yield of grain crops of the order of 60$80 \mathrm{c} / \mathrm{ha}$ has become common and stable $[1,2,3]$. The growth of crop production was due to the use of mineral fertilizers, herbicides, fungicides, insecticides, growth regulators, the introduction of new high-yield varieties, a high level of agricultural technology for the cultivation of agricultural crops [4,5].

At the same time, widespread chemicalization caused the appearance of toxic substances and compounds harmful to human health in food products, contributed to the pollution of the environment with nitrates, pesticides, and heavy metals [6,7]. In this regard, an urgent need arose for the development of alternative technologies (biological, ecological) for the cultivation of agricultural crops, ensuring the receipt of ecologically safe crop production. That is, the main and most promising trend in the development of modern agriculture is currently the biologization of agricultural technologies [8, 9].

Agroecological requirements of agricultural crops for soil and climatic conditions within a given agroecological group of lands, as well as a certain production and resource potential of a commodity producer, based on the yield that is planned and, accordingly, the quality of production in the system of ecological limitation of technogenesis must be considered with the use of new generation agricultural technologies $[10,11]$.

Based on a rational combination of different levels of biologization and fertilization systems, which ensure high and stable yields with high grain quality, technologies for the cultivation of winter wheat are being developed, which are of great theoretical and practical importance $[12,13]$.

The research aimed to determine the influence of technologies for the cultivation of winter wheat with different levels of biologization on the yield and quality of the grain, reducing labor, energy costs, and fertility of typical chernozem.

\footnotetext{
* Corresponding author: Nikioxana2009@yandex.ru
} 


\section{Materials and methods}

The research was carried out in the stationary experience of the department of technologies for highly productive rational land use based on the Kursk FANTS Federal State Budgetary Scientific Institution in 2018-2020. in a crop rotation with the following crop rotation: clover $1 \mathrm{gp}$ - winter wheat - sugar beet spring wheat - peas / oats - winter rye - buckwheat oats - barley + clover.

The efficiency of winter wheat cultivation was studied using technologies with different levels of biologization. The experiment scheme included the following options:

1. Extensive technology (control): plowing by 20 $22 \mathrm{~cm}$, without fertilization, pesticide treatment of crops, considering the economic threshold of harmfulness. The need of plants for nutrients is provided at the expense of soil resources;

2. Intensive technology: plowing by $20-22 \mathrm{~cm}$, application of mineral fertilizers in a dose of N120P120K120, treatment of crops with pesticides, considering the economic threshold of harmfulness. The need of plants for nutrients is $100 \%$ provided by mineral fertilizers;

3 Biotechnology: plowing by $20-22 \mathrm{~cm}$, green fertilizer + manure 60 t/ha + biological products, treatment of crops with pesticides, considering the economic threshold of harmfulness. Due to organic fertilizers, $100 \%$ of the need for plants in nutrients is provided;

4. Combined technology: plowing by $20-22 \mathrm{~cm}$, green fertilizer + manure $30 \mathrm{t} / \mathrm{ha}+\mathrm{N} 60 \mathrm{P} 60 \mathrm{~K} 60+$ biological products, treatment of crops with pesticides, considering the economic threshold of harmfulness. Due to mineral fertilizers, $50 \%$ of the needs of plants for nutrients are provided, and 50\% are provided due to organic fertilizers.

The experiment was repeated 3 times. The location of the plots is systematic, the area of the experimental plot is $100 \mathrm{~m} 2$. Winter wheat variety Ermak. Sowing rate: 5 million viable seeds per hectare.

The meteorological conditions during the years of the experiment were typical for the Kursk region. The growing season of winter wheat in 2018 was characterized by cool and humid weather. The average daily temperature in April - July was $0.2^{\circ} \mathrm{C}$ lower than the long-term average, with the total precipitation being $126.5 \%$ of the norm $(215 \mathrm{~mm})$. The average daily temperature April - July 2019 and 2020 was 14.2 and $14.9^{\circ} \mathrm{C}$ with an average long-term temperature of this period equal to $14.2^{\circ} \mathrm{C}$, and the amount of precipitation was $197.5-213.6 \mathrm{~mm}$, or $91.9-99.3 \%$ of the norm. In 2019, the weather was warm with a lack of precipitation. In general, during the growing season, the heat supply turned out to be higher than the longterm one. Wintering of winter crops took place in satisfactory conditions. The course of wintering was complicated by thaws, which contributed to the weakening of plants and reduced their winter hardiness. In 2020, warm weather with a lack of precipitation was observed. Precipitation throughout the year was unevenly distributed in intensity. A significant deficit of precipitation was noted in August and September. The heat supply of the growing season was sufficient. Good agricultural conditions prevailed for the formation of agricultural crops. Deteriorated in certain periods of development with the appearance of unfavorable agrometeorological phenomena. Winter crops were harvested under favorable weather conditions.

The soil of the experimental site is represented by typical thick heavy loamy chernozem. The content of humus in the arable layer is $6.1 \%$, mobile phosphorus (according to Chirikov) - $15.6 \mathrm{mg} / 100 \mathrm{~g}$ of soil, exchangeable potassium (according to Maslova) - 11.3 $\mathrm{mg} / 100 \mathrm{~g}$ of soil. The reaction of the soil medium is neutral (pH 6.5).

Harvesting and accounting of the winter wheat harvest were carried out by a Sampo-500 combine by direct combining. The harvest was recalculated for $100 \%$ purity and $14 \%$ grain moisture. In grain samples, the content of wet gluten (GOST 54478-2011), the nature of the grain (GOST 10840-2017), and the mass of 1000 grains (GOST 10842-89) were determined. The experimental data were processed by the method of analysis of variance.

\section{Results and discussion}

As a result of the research, it was found that technologies with different levels of biologization in the cultivation of winter wheat have a significant effect on the content of nitrate-nitrogen and available moisture in the soil, weediness of crops, grain quality, and yield.

Observations of the soil moisture regime under winter wheat during the years of the experiment showed that the moisture supply of its crops depended on the meteorological conditions of the year and the fertilization system. Higher reserves of available moisture in the topsoil before sowing winter wheat were noted in 2018 and 2019, which is associated with a higher amount of precipitation in July-August (154.6 and $174.4 \mathrm{~mm}$ or 114.5 and $129.2 \%$ of the norm, respectively). In JulyAugust 2020, the amount of precipitation was $73.2 \mathrm{~mm}$ or $54.2 \%$ of the norm.

The moisture supply of winter wheat in the autumn growing season was significantly influenced by fertilization systems with different levels of biologization. So, during the cultivation of winter wheat using intensive technology with a mineral fertilization system, the reserves of productive moisture in the arable layer of the soil were practically equal to the moisture reserves in the arable layer. 
Table 1. Influence of cultivation technologies with different levels of biologization on the reserves of available moisture in the topsoil before sowing winter wheat

\begin{tabular}{|c|c|c|c|c|c|c|}
\hline \multirow[t]{3}{*}{ Technology } & \multirow[t]{3}{*}{ Fertilization system } & \multirow{3}{*}{$\begin{array}{l}\text { How the need for } \\
\text { batteries is satisfied }\end{array}$} & \multicolumn{4}{|c|}{ Available moisture reserves, $\mathrm{mm}$} \\
\hline & & & \multicolumn{4}{|c|}{ years } \\
\hline & & & 2018 & 2019 & 2020 & $\begin{array}{l}\text { Average over } \\
3 \text { years }\end{array}$ \\
\hline Extensive & No fertilizers & $\begin{array}{l}100 \% \text { due to natural } \\
\text { soil fertility }\end{array}$ & 15.0 & 18.2 & 8.4 & 13.8 \\
\hline Intensive & $\begin{array}{l}\text { Mineral } \\
\left(\mathrm{N}_{120} \mathrm{P}_{120} \mathrm{~K}_{120}\right)\end{array}$ & $\begin{array}{l}100 \% \text { due to mineral } \\
\text { fertilizers }\end{array}$ & 14.9 & 18.6 & 8.3 & 13.9 \\
\hline Biological & $\begin{array}{l}\text { Organic (manure } 60 \mathrm{t} \\
/ \text { ha }+ \text { fertilization }+ \\
\text { biological product) }\end{array}$ & $\begin{array}{l}100 \% \text { from organic } \\
\text { fertilizers }\end{array}$ & 16.8 & 19.9 & 9.6 & 15.4 \\
\hline Combined & $\begin{array}{l}\text { Organo-mineral } \\
\text { (manure } 30 \mathrm{t} / \text { ha }+ \\
\text { fertilization } \\
\mathrm{N}_{60} \mathrm{P}_{60} \mathrm{~K}_{60}+ \\
\text { preparation) }\end{array}$ & $\begin{array}{l}50 \% \text { due to mineral, } \\
50 \% \text { due to organic } \\
\text { fertilizers }\end{array}$ & 15.7 & 19.3 & 9.2 & 14.7 \\
\hline \multicolumn{3}{|l|}{ HCP05 } & & & & 0.6 \\
\hline
\end{tabular}

In 2018, the reserves of available moisture in the arable layer with intensive technology were the smallest values, compared with other technologies and amounted to $15.0 \mathrm{~mm}, 0.1 \mathrm{~mm}$ were higher than the reserves of moisture with extensive technology. The largest reserves of moisture in the arable layer were observed with biological technology using fertilization systems, manure 60 t/ha with green fertilizers, and a biological product and amounted to $16.8 \mathrm{~mm}$. In 2019 , almost the same pattern was observed, but the smallest moisture reserves in the arable layer were observed when using extensive technology, that is, without fertilizers, and amounted to $18.2 \mathrm{~mm}$. The reserves of available moisture slightly increased in the variant of the experiment with intensive technology and amounted to $18.6 \mathrm{~mm}$. The largest reserves of available moisture were observed in the variant with the use of biological technology and amounted to $19.9 \mathrm{~mm}$, the reserves of available moisture were slightly lower in the variant with the combined technology when manure was used in the fertilizer system $30 \mathrm{t} / \mathrm{ha}$, green fertilizer, N60P60K60, and biological product - 19.3 $\mathrm{mm}$. In 2020, the available moisture reserves are much less than in previous years, but the trend in the ratio of the available moisture content is the same as in 2019 , that is, the minimum content of available moisture reserves was observed with intensive technology and amounted to $8.3 \mathrm{~mm}$, the highest content of available moisture reserves was observed with biological technology and amounted to $9.6 \mathrm{~mm}$.
Consequently, in the topsoil, they were practically equal to the moisture reserves under winter wheat cultivated using extensive technology (without fertilization). In variants with the cultivation of winter wheat according to the technology with a $50 \%$ level of biologization (manure $30 \mathrm{t} / \mathrm{ha}+$ plowing of green fertilizers + N60P60K60), the reserves of productive moisture in the topsoil increased by $0.9 \mathrm{~mm}$. An increase in the level of biologization to $100 \%$ (manure $60 \mathrm{t} /$ ha + plowing of green fertilizer) contributed to an increase in the reserves of productive moisture in the topsoil by 1.6 $\mathrm{mm}$.

Higher reserves of nitrate-nitrogen $(106.7 \mathrm{~kg} / \mathrm{ha})$ in the $0-40 \mathrm{~cm}$ soil layer before sowing winter wheat were noted in variants where it was cultivated using biotechnology with $100 \%$ provision of mineral nutrition elements due to organic fertilizers (manure $60 \mathrm{t} / \mathrm{ha}+$ green fertilizer + biological product). A decrease in the level of biologization of the winter wheat cultivation technology to $50 \%$ led to a decrease in nitrate-nitrogen reserves to 104.2 $\mathrm{kg} / \mathrm{ha}$.

By the time of the resumption of the spring vegetation of winter wheat, the reserves of nitrate-nitrogen in the $0-40 \mathrm{~cm}$ soil layer increased to $118.4-131.5 \mathrm{~kg} / \mathrm{ha}$, but the difference between the variants remained. The minimum reserves of nitrate-nitrogen were observed before the harvesting of winter wheat and amounted to $18.8-19.6 \mathrm{~kg} / \mathrm{ha}$, and there was practically no difference in the variants of the experiment and, accordingly, it can be said that when cultivating winter wheat using various technologies, the reserves of nitratenitrogen at the time of harvesting of the crop leveled off. 


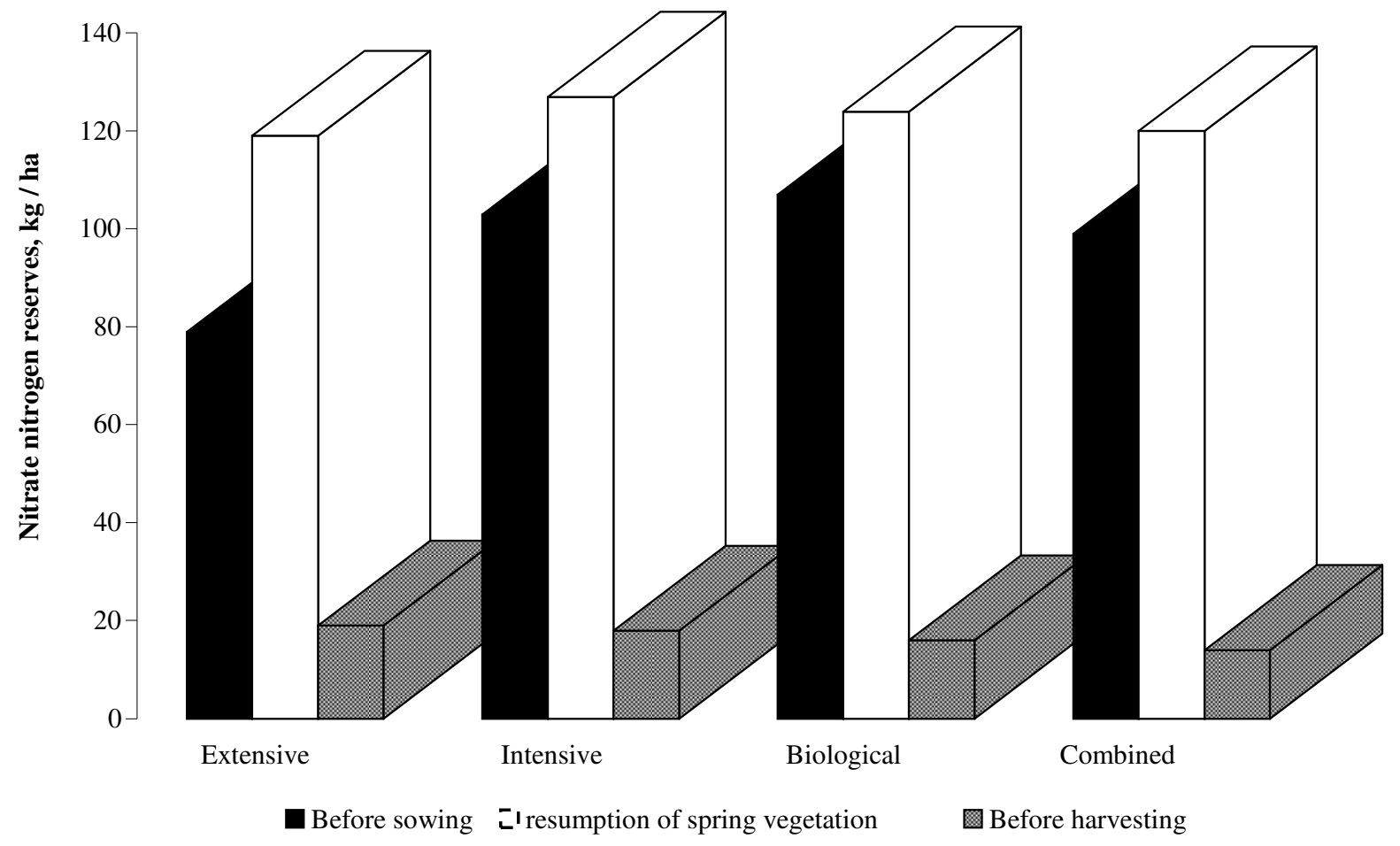

Figure 1. Influence of cultivation technologies with different levels of biologization on the stocks of nitrate nitrogen in the soil before sowing winter wheat: extensive, intensive, biological, combined

Table 2.Influence of cultivation technologies with different levels of biologization on weediness of winter wheat crops, 2018-2020

\begin{tabular}{|c|c|c|c|c|c|c|}
\hline \multirow[t]{3}{*}{ Technology } & \multirow[t]{3}{*}{ Fertilization system } & \multirow{3}{*}{$\begin{array}{l}\text { How the need for } \\
\text { batteries is satisfied }\end{array}$} & \multicolumn{4}{|c|}{ Weediness of winter wheat crops } \\
\hline & & & \multicolumn{2}{|l|}{ spring } & \multicolumn{2}{|l|}{ autumn } \\
\hline & & & $\mathrm{pcs} / \mathrm{m}^{2}$ & $\mathrm{~g} / \mathrm{m}^{2}$ & $\mathrm{pcs} / \mathrm{m}^{2}$ & $\mathrm{~g} / \mathrm{m}^{2}$ \\
\hline Extensive & No fertilizers & $\begin{array}{l}100 \% \text { due to natural } \\
\text { soil fertility }\end{array}$ & 58.1 & 40.6 & 70.2 & 48.5 \\
\hline Intensive & $\begin{array}{l}\text { Mineral } \\
\left(\mathrm{N}_{120} \mathrm{P}_{120} \mathrm{~K}_{120}\right)\end{array}$ & $\begin{array}{l}100 \% \text { due to mineral } \\
\text { fertilizers }\end{array}$ & 59.8 & 44.9 & 72.7 & 115.6 \\
\hline Biological & $\begin{array}{l}\text { Organic } \text { (manure } \\
60 \mathrm{t} / \text { ha }+ \\
\text { fertilization }+ \\
\text { biological product) }\end{array}$ & $\begin{array}{l}100 \% \text { from organic } \\
\text { fertilizers }\end{array}$ & 70.6 & 72.4 & 92.0 & 95.5 \\
\hline Combined & $\begin{array}{l}\text { Organo-mineral } \\
\text { (manure } 30 \mathrm{t} / \mathrm{ha}+ \\
\text { fertilization } \\
\mathrm{N}_{60} \mathrm{P}_{60} \mathrm{~K}_{60}+ \\
\text { preparation) }\end{array}$ & $\begin{array}{l}50 \% \text { due to mineral, } \\
50 \% \text { due to organic } \\
\text { fertilizers }\end{array}$ & 63.3 & 69.3 & 77.8 & 89.3 \\
\hline
\end{tabular}

The application of mineral fertilizers $\left(\mathrm{N}_{120} \mathrm{P}_{120} \mathrm{~K}_{120}\right)$ had practically no effect on the number of weeds in winter wheat crops $(59.8-72.7 \mathrm{pcs} / \mathrm{m} 2)$ in comparison with the options where no mineral fertilizers were applied (58.1$70.2 \mathrm{pcs} / \mathrm{m} 2$ ). The highest weediness of winter wheat crops in all the years of research was noted during its cultivation according to biotechnology - 70.6-92.0 $\mathrm{pcs} / \mathrm{m} 2$. That is, the use of organic fertilizers (manure 60 $\mathrm{t} / \mathrm{ha}+$ green fertilizer) contributed to an increase in weediness of winter wheat crops (by 10.8-19.3 pcs/m2), in comparison with the mineral fertilization system (Table 2). The highest yield of winter wheat in all the years of research (5.98 t/ha) was obtained by cultivating it using intensive technology, in which $100 \%$ of the need for nutrients is provided by mineral fertilizers (N60P120K120 for plowing + $\mathrm{N} 30$ for feeding in early spring $+\mathrm{N} 30$ during exit into the earing tube). 
Table 3. Influence of cultivation technologies with different levels of biologization on the yield and quality of winter wheat grain (2018-2020)

\begin{tabular}{|c|c|c|c|c|c|c|}
\hline Technology & Fertilization system & $\begin{array}{l}\text { How the need for } \\
\text { batteries is satisfied }\end{array}$ & $\begin{array}{l}\text { Producti } \\
\text { vity, t/ha }\end{array}$ & $\begin{array}{l}+ \text { to } \\
\text { control }\end{array}$ & $\begin{array}{l}\text { Gluten } \\
\text { content, \% }\end{array}$ & $\begin{array}{l}+ \text { to } \\
\text { control }\end{array}$ \\
\hline Extensive & No fertilizers & $\begin{array}{l}100 \% \text { due to natural } \\
\text { soil fertility }\end{array}$ & 3.95 & - & 23.6 & - \\
\hline Intensive & $\begin{array}{l}\text { Mineral } \\
\left(\mathrm{N}_{120} \mathrm{P}_{120} \mathrm{~K}_{120}\right)\end{array}$ & $\begin{array}{l}100 \% \text { due to mineral } \\
\text { fertilizers }\end{array}$ & 5.98 & 2.03 & 26.9 & 3.3 \\
\hline Biological & $\begin{array}{l}\text { Organic (manure } \\
60 \mathrm{t} / \text { ha }+ \\
\text { fertilization } \\
\text { biological product) }\end{array}$ & $\begin{array}{l}100 \% \text { from organic } \\
\text { fertilizers }\end{array}$ & 5.41 & 1.46 & 25.9 & 2.3 \\
\hline Combined & $\begin{array}{l}\text { Organo-mineral } \\
\text { (manure } 30 \mathrm{t} / \mathrm{ha}+ \\
\text { fertilization } \\
\mathrm{N}_{60} \mathrm{P}_{60} \mathrm{~K}_{60}+ \\
\text { preparation) }\end{array}$ & $\begin{array}{l}50 \% \text { due to mineral, } \\
50 \% \text { due to organic } \\
\text { fertilizers }\end{array}$ & 5.87 & 1.92 & 26.5 & 2.9 \\
\hline \multicolumn{3}{|l|}{$\mathrm{HCP05}$} & \multicolumn{2}{|l|}{0.21} & \multicolumn{2}{|l|}{0.4} \\
\hline
\end{tabular}

In variants with the cultivation of winter wheat using technology with a $50 \%$ level of biologization (manure $30 \mathrm{t} / \mathrm{ha}+$ plowing of green fertilizers + N60P60K60 + biological product), the yield of winter wheat was 5.87 $\mathrm{t} / \mathrm{ha}$, or $1.92 \mathrm{t} / \mathrm{ha}$ higher than with cultivation it uses extensive technology (without fertilization).

The efficiency of winter wheat cultivation using biotechnology, in which $100 \%$ of the need for nutrients is provided by organic fertilizers (manure $60 \mathrm{t} / \mathrm{ha}+$ green fertilizer + biological product) was slightly lower: its yield in this variant was $5.41 \mathrm{t} / \mathrm{ha}$, or 1.46 t/ha higher than in the variant without fertilization (extensive technology). With the cultivation of winter wheat according to the extensive technology, the gluten content in the grain of the cultivated crop was $23.6 \%$. Higher content of wet gluten in winter wheat grain was obtained by cultivating it according to intensive technology with the fractional application of nitrogen fertilizers - $26.9 \%$ (in the control variant, the content of wet gluten was $23.6 \%$ ).

The combined technology of winter wheat cultivation, in which $50 \%$ of the need for nutrients is provided by mineral fertilizers, and $50 \%$ by organic fertilizers, contributed to an increase in the content of crude gluten in winter wheat grain by $2.9 \%$. With the cultivation of winter wheat using biotechnology with $100 \%$ supply of plants with mineral nutrition elements due to organic fertilizers, the content of crude gluten in the grain was $25.9 \%$, or $2.3 \%$ higher, in comparison with its cultivation using extensive technology (without fertilization).

Analyzing Table 3, we can conclude that when using intensive technology, in which the need for nutrients is satisfied by $100 \%$ due to mineral fertilizers, the highest yield of winter wheat (5.98 t/ha) was obtained and in the grain of the crop the gluten content exceeds, by compared to other technologies. The yield with the combined technology decreases slightly - by $0.11 \mathrm{t} / \mathrm{ha}$, the quality of gluten is lower by $0.4 \%$.

\section{Conclusion}

As a result of the research, it was found that the efficiency of cultivation of winter wheat using technology, with a $50 \%$ level of biologization, including an organomineral fertilization system, was practically equal to the efficiency of cultivation using intensive technology with a high level of material costs, and $100 \%$ of the provision of plant needs. in food elements due to mineral fertilizers. The cultivation of winter wheat using biotechnology with a $100 \%$ supply of plant requirements for nutrients due to organic fertilizers, although it led to a decrease in the productivity of winter wheat by $9.6 \%$, however, contributed to a decrease in anthropogenic load on the soil and the production of environmentally safe products.

\section{References}

1. V. I. Kiryushin, S. V. Kiryushin, Agrotechnology: Textbook (Lan, St. Petersburg, 2015).

2. A. A. Zhuchenko, Ecological genetics of cultivated plants and problems of the agrosphere (theory and practice). Monograph (Agrorus, volume 1, 2004).

3. Technologies of the XXI century in the agroindustrial complex of Russia (Moscow: Russian Agricultural Academy, 2011).

4. V. I. Kiryushin, Greening Agriculture and Technological Policy (Moscow: Moscow Agricultural Academy, 2000).

5. A. L. Ivanov, A. A. Zavalin, Agriculture, 7, 3-6 (2010).

6. V. E. Shevchenko, V. N. Fedotov, Biologization and adaptive intensification of agriculture in the Central Black Earth Region (Voronezh, 2000). 
7. N. Z. Milashchenko, S. V. Trushkin, Fertility, 3, 50-52 (2011).

8. V. A. Semykin, I. Ya. Pigorev, Problems of the development of agriculture in the Central Chernozem region: materials of the All-Russian scientific-practical conference (Kursk: Publishing house of the KGSKhA, 2005).

9. A. V. Gostev, The effectiveness of technologies of different levels of intensity in the cultivation of grain crops on chernozem soils of the Central Chernozem region (Kursk: FGBNU VNIIZiZPE, 2017).

10. G. N. Cherkasov et al., Theoretical foundations for the formation of an agro-technological policy for the use of zero and surface tillage for grain crops for the modernization of agriculture (Kursk: GNU VNIIZiZP, 2012).

11. V. I. Lazarev, R. I. Lazarev, B. S. Ilyin, J. N. Minchenko, International Agricultural Journal, 5, 12-15 (2019).

12. V. I. Lazarev, A. Ya. Aydiev, M. N. Kotelnikova, Agriculture, 1, 37-39 (2017).

13. V. A. Semykin, I. Ya. Pigorev, O. V. Nikitina, Bulletin of the Kursk State Agricultural Academy, 3, 6-11 (2019) 